PROBLEMS

OF EDUCATION

IN THE $21^{\text {st }}$ CENTURY

Vol. 77, No. 5, 2019

568

\title{
FOSTERING PEACE CULTURE BY INTERCULTURAL DIALOGUE IN EDUCATION
}

\author{
Agnaldo Arroio \\ University of Sao Paulo, Brazil \\ E-mail: agnaldoarroio@yahoo.com
}

This manuscript wishes to discuss something that could be considered the oldest and the newest of themes: Peace.

Peace is not just the absence of war. It may be that in your country or region there is no armed conflict. But is there peace? But then what does living in peace mean if it is not just the absence of war or conflict? It is living together with each other's differences - gender, ethnicity, language, religion and culture - while nurturing universal respect for justice and human rights is shared and coexistence based. In this sense, peace is permanently under construction and needs the participation of all, as it is the choice that encompasses sincere dialogue with other individuals and communities. And here we have a key role for education in promoting a culture of peace, from young children to adult.

Almost 10 years ago, the United Nation Security Council underlined the vital role of intercultural dialogue in preserving world peace at a session in which Secretary-General Ban Ki-moon warned that while the world is increasingly linked through migration, trade and technology, it is also increasingly separate.

At that time Mr. Ban Ki-moon stressed that while countries make more frequent contact with each other and that many of them are increasingly multicultural and diverse, this enrichment, which many celebrate, in some cases can confuse and intimidate others.

Today, in 2019, we are close to the end of the International Decade for the Approximation of Cultures promoted between 2013 and 2022, that started taking into account the notion that international security and social inclusion could only be achieved through the joint work of different countries and cultures. It aimed to eradicate prejudice and stereotypes that give rise to it through intercultural dialogue. Are we going to achieve it until 2022, or how much did we move forward since 2013 to today?

The construction of peace is strengthened by the growing vision of global interdependence and universal responsibility for building a new world and places on this theme as one of the main educational actions that promote effective sources of peace in the world. But more than Peace it is necessary the Culture of Peace for a new world.

Considering as a movement, the Culture of Peace was officially started by UNESCO (United Nations Educational, Scientific and Cultural Organization) in 1999 and strives to prevent situations that may threaten peace and security - such as disrespect for human rights, discrimination and intolerance, social exclusion, extreme poverty and environmental degradation - using awareness, education and prevention as key tools. According to UNESCO, the culture of peace "is intrinsically related to non-violent conflict prevention and resolution" and is based on the principles of tolerance, solidarity, respect for life, individual rights and pluralism.

Taking it into account the modern era began when the human being has mastered the world. At the same time the knowledge produced allowed the industrial revolution, the 
developments in Science and Technology and a revolution in information technology. The human being has evolved, advanced, modernized, created better living conditions, health, and food made life more comfortable.

While there is a lot of information, technology and knowledge available, which makes the world increasingly interconnected, it does not mean that individuals and societies are living together, with peace and justice for all. Adequate knowledge is still needed to prevent conflict, eradicate poverty or enable everyone to learn to live in harmony in a safe world.

This human being also has oppressed innumerable other humans. How this humankind allowed issues like racism, oppression of minorities, gender-based discrimination, poverty and exclusion of refugees. What does it mean to be human?

The peace culture proposal seeks alternatives and solutions to these issues that afflict humanity as a whole, not focusing on the issue of violence, but on peace as a social state of dignity where everything can be preserved and respected. These points are one of the great challenges of building a culture of peace. In this sense the intercultural dialogue promoted by education could be able to foster this peace culture process.

Today in this polarized world, more than ever, it is necessary to promote values, attitudes and behaviours that foster intercultural dialogue, non-violence, tolerance and rapprochement of cultures, central principles to the UNESCO Universal Declaration of Cultural Diversity, stated in 2001 .

The promotion of racism and hate speech by political figures encourages crimes; this kind of populist manoeuvre turns political leaders into accomplices of episodes of violence. It is almost unimaginable that public people, such as politicians, promote hate speech and intolerance (Arroio, 2019).

As stated by human rights expert Tendayi Achiume "The increasing use of sectarian language and attempts to marginalize racial, ethnic and religious minorities in political discourse have acted as a call to action, fostering violence, intolerance and fanaticism."

Mr. Ban Ki-moon said "At a time when prejudice and hatred are too common, when extremists seek to recruit more supporters through incitement and identity-based appeals, where politicians use division as a strategy to win elections, dialogue can be an antidote", so do not forget that education is based on dialogue between teacher-students, students-students, teachers-teachers, teacher-community, and students-community and on.

This movement represents an opportunity for participation that opens doors for all together to work on the possibilities of transforming a culture driven by distrust, competition and misuse of power into a Culture of Peace, dialogue and shared responsibility.

As Tendayi Achiume highlighted "The use (of questions) of race to instil fear, win votes or power, or mask injustices, must end. Those who have privilege and power have a strong responsibility to mitigate - not encourage - racism, intolerance and fanaticism. Communities and leaders throughout the world must seriously take on their obligations to prevent further tragedy and to protect the human rights of all equally and without conditions."

The promotion of intercultural dialogue could start at school, including this discussion in different contexts, and also exploring the key role of information and communication technologies to do it. Just pay attention to how these intolerant people' social media manifestos and publications reflect a political discourse that devalues and dehumanizes people based on race, ethnicity, religion, or immigration status.

Peace and Peace Culture is at the heart of UNESCO's mission, so contributing to cultural pluralism based on cultural exchanges and contacts between individuals and groups from different cultural backgrounds becomes crucial.

Here in this journal Problems of Education in the $21^{\text {st }}$ Century you can find a diverse scope of educational perspectives, projects, practices, research from all over the world, take a time to know and understand how education is going on in different countries, how the cultural

$\mid$\begin{tabular}{l} 
PROBLEMS \\
OF EDUCATION \\
IN THE 21 $1^{\text {st }}$ CENTURY \\
Vol. 77, No. 5, 2019 \\
\hline 569
\end{tabular} 
PROBLEMS

OF EDUCATION IN THE $21^{\text {st }}$ CENTURY Vol. 77, No. 5, 2019

570

aspects shape their practices, don't look just at your peers in subject or country, give yourself a chance to expand your repertoire and your knowledge about education in a more opened eyes.

Dialogue between cultures is therefore an essential factor in building a culture of peace. At the same time, it plays a very important role in social cohesion, as societies are increasingly heterogeneous and have elements from different cultural backgrounds.

Considering the 2030 Agenda the SDG (Sustainable Development Goals) 4 - ensure inclusive and equitable quality education and promote lifelong learning opportunities for all, in special target 4.7 - by 2030, ensure that all learners acquire the knowledge and skills needed to promote sustainable development, including, among others, through education for sustainable development and sustainable lifestyles, human rights, gender equality, promotion of a culture of peace and non-violence, global citizenship and appreciation of cultural diversity and of culture's contribution to sustainable development.

How we are reaching this indicator 4.7.1 - extent to which (i) global citizenship education and (ii) education for sustainable development, including gender equality and human rights, are mainstreamed at all levels in: (a) national education policies, (b) curricula, (c) teacher education and (d) student assessment.

This phenomenon makes societies an extremely rich and ever-changing organism. In addition, intercultural dialogue also contributes to the richness of cultural and artistic productions, as it favours syncretism and the emergence of different readings and interpretations of a single cultural good.

Culture of Peace requires active investment, enlightened leadership, powerful educational values, extensive research on social innovation, and a progressive media environment (Arroio, 2017). Each of these is a relevant requirement for UNESCO's mission. The Organization contributes to world peace through its commitments to the development of education and science, the enrichment of cultural creativity, memory and the cultural future, including a vibrant and peace-oriented global media structure.

Prime Minister Saad Hariri of Lebanon said during the session on "Intercultural Dialogue for Peace and Security", in 2010, the dialogue was based on the recognition of identities and depended on not allowing the affirmation of those identities to turn into hostility. Dialogue in culture, society and politics is the way to preserve unity and to enrich ourselves with plurality, he added, saying these goals were at the heart of his country's insistence on parity between Muslims and Christians, as stipulated in the Agreement of 1989, which ended the civil war in Lebanon.

Following this Intercultural dialogue is an important element in maintaining peace, it is crucial to avoid associating any religion or culture with the evils that plague the international community, such as terrorism. Also, it can only be truly effective when it is frank and includes all sectors of society, in particular women.

Take a look at SDG 4 - target 4.5 - by 2030 , eliminate gender disparities in education and ensure equal access to all levels of education and vocational training for the vulnerable, including persons with disabilities, indigenous peoples and children in vulnerable situations. This could be achieved by these indicators as parity indices (female/male, rural/urban, bottom/ top wealth quintile and others such as disability status, indigenous peoples and conflict-affected, as data become available) for all education indicators on this list that can be disaggregated.

It is essential to ensure a harmonious interaction between people and groups with plural, varied and dynamic cultural identities, as well as their willingness to live together. Policies for the inclusion and participation of all citizens are guarantees of peace, social cohesion and vitality of civil society.

Also, SDG 4 expect by 2030, to substantially increase the supply of qualified teachers, including through international cooperation for teacher training in developing countries, especially least developed countries and small island developing States. According to the 
indicators, the proportion of teachers in: (a) pre-primary; (b) primary; (c) lower secondary; Vol. 77, No. 5, 2019 and (d) upper secondary education who have received at least the minimum organized teacher training (e.g. pedagogical training) pre-service or in-service required for teaching at the relevant level in a given country.

The readers of this scientific journal are members of education international community, so how the international cooperation is supporting the intercultural dialogue between partners during the cooperation projects for research and teaching and learning in Education.

Education plays a key role in building sustainable, inclusive and resilient societies based on the Culture of Peace. Highlighting that teachers are one of the most powerful forces in achieving inclusive and equitable education for all, but there is a global shortage of qualified teachers.

It is worth remembering that in order to build a more humane society, it is essential that each one starts with oneself and does their part through a change in attitudes, values and behaviours aimed at building a fairer and better world to live in.

\section{References}

Arroio, A. (2019). Education as a Human Right against hate speech and intolerance. Problems of Education in the 21st Century, 77(3), 314-316.

Arroio, A. (2017). Is media literacy an urgent issue in education for all? Problems of Education in the 21st Century, 75(5), 416-418.

UNESCO - Universal Declaration of Cultural Diversity, 2001. Retrieved from https://unesdoc.unesco. org/ark:/48223/pf0000124687.page $=67$

Intercultural Dialogue Crucial in Preventing, Resolving Conflicts, Secretary-General Tells Security Council Thematic Debate on 26 may 2010. Retrieved from https://www.un.org/press/en/2010/ sc9936.doc.htm

United Nations Human rights experts Special Rapporteur E. Tendayi Achiume - US shootings: Use of racist language to gain votes or power must stop. UN rights experts on 7 August 2019. Retrieved from https://www.ohchr.org/EN/NewsEvents/Pages/DisplayNews.aspx?NewsID=24875\&LangID=E

United Nations - Sustainable Development Goals - 2030 Agenda. Retrieved from https://www.un.org/ sustainabledevelopment/.

Received: August 30, 2019

Accepted: October 01, 2019

Agnaldo Arroio

PhD, Professor, University of Sao Paulo, Brazil \& Editor-in-Chief of Problems of

Education in the $21^{\text {st }}$ Century.

E-mail: agnaldoarroio@yahoo.com

Website: https://www.researchgate.net/profile/Agnaldo_Arroio 